\title{
Spatial modeling of leprosy in the state of Bahia and its social determinants: a study of health inequities ${ }^{*}$
}

\author{
Carlos Dornels Freire de Souza ${ }^{1,2}$, Carlos Feitosa Luna ${ }^{2,3}$, Mônica de Avelar Figueiredo Mafra Magalhães ${ }^{4}$
}

DOI: http:/ / dx.doi.org/10.1590/abd1806-4841.20197554

\begin{abstract}
BACKGROUND: Leprosy is a neglected disease caused by Mycobacterium leprae. Brazil has the second largest number of cases in the world.

OвJестіves: To analyze the spatial distribution of leprosy in the state of BAHIA, Brazil, and the association between his occurrence and the synthetic indicators of municipal socioeconomic performance, social vulnerability and income inequality. Methods: An ecological study with secondary data obtained from the National System of Notifiable Diseases. Dependent variables: coefficient of detection in the general population and in the population under 15 years old and the rate of grade II of physical disability. Independent variables: Synthetic indicators of socioeconomic performance, social vulnerability and income inequality.

RESUlTS: The highest coefficients of detection of new cases in the general population and in children under 15 years old are concentrated in the north-west axis and in the southern region of the state. On the other hand, the highest rates of degree II of physical incapacity are concentrated in the north, northeast and south regions. Only the Index of Social and Economic Performance(IPESE)-Economy and Finance composed the final regression model of the general detection coefficients and in children under 15 years old. The municipalities with the highest indexes had the highest detection coefficients, reflecting the capacity to diagnose new cases.

Study Limitations: The use of synthetic indicators is a limitation of the study.

CONCLUSIONS: Leprosy presents a heterogeneous spatial pattern in the state of BAHIA, and the IPESE-Economics and Finance indicator is the only one with explanatory potential of the disease.
\end{abstract}

Keywords: Epidemiology; Leprosy; Mycobacterium leprae; Public health

\section{INTRODUCTION}

Hansen's disease is a chronic and granulomatous neglected tropical disease caused by Mycobacterium Leprae or Hansen bacillus. It is a bacillus with high infectivity that attacks cutaneous and peripheral nerve cells, leading to dermato-neurological lesions that can range from a single lesion with decreased sensation to systemic involvement and permanent physical disabilities, besides psychosocial distress. ${ }^{1-4}$

Since the introduction of polychemotherapy in the 1980s, there was a marked reduction in the burden of Hansen's disease worldwide, reaching the elimination level in 2000 as a worldwi-

\footnotetext{
$\overline{\text { Received } 21 \text { August 2017. }}$

Accepted 22 January 2018.

* Work conducted at Instituto Aggeu Magalhães, Fundação Oswaldo Cruz, Recife (PE), Brazil.

Financial Support: None.

Conflict of Interests: None.

Discipline of Collective Health, Curso de Medicina, Universidade Federal de Alagoas, Arapiraca (AL), Brazil.

Instituto Aggeu Magalhães, Fundação Oswaldo Cruz, Recife (PE), Brazil.

Program of Post-Graduation in Public Health, Fundação Oswaldo Cruz, Recife (PE), Brazil.

Instituto de Comunicação e Informação Científica e Tecnologia em Saúde, Fundação Oswaldo Cruz, Rio de Janeiro (RJ), Brazil.
}

E-mail: carlos.freire@arapiraca.ufal.br 
de health issue, although 15 nations were not able to achieve that then. Only in 2014, 213,899 new cases of the disease were registered throughout the world, being $18,869(8.8 \%)$ of them in the child population. ${ }^{5}$ Ninety-four percent of cases were concentrated in 13 nations of the globe, with the first positions occupied by India and Brazil, respectively. India has the largest number of Hansen's disease cases but Brazil occupies the first position in prevalence, being the only one that did not achieve the target of elimination of the disease as a public health issue. ${ }^{5}$

In Brazil, the distribution of Hansen's disease is very heterogeneous. While some States have very low coefficients of detection, such as Rio Grande do Sul and Santa Catarina - with coefficients of 1.08 and 2.51/100.000 inhabitants in 2015, respectively - others, such as Mato Grosso, had a coefficient higher than 90 new cases per 100.000 inhabitants for the same year. ${ }^{6}$

Considering the absolute numbers of new diagnoses, the northeastern region occupied the first position in 2015, with 12,848 cases, corresponding to $44.7 \%$ of all patients notified all over the country. The distribution of Hansen's disease is not homogeneous in the region either. While Rio Grande do Norte registered a coefficient of 7.81/100.000 inhabitants, in the State of Maranhão the coefficient reached 51.27/100.000. The State of Bahia occupies an intermediate position in the ranking of Hansen's disease burden in Brazil. In 2015, the State occupied the $11^{\text {th }}$ national position and the $5^{\text {th }}$ among the northeastern States, with a global detection coefficient of $16.76 / 100.000$, above the national mean for the same period $(14.07 / 100.000) .^{6}$

The search for explanations regarding the factors that act as determinants for the occurrence of Hansen's disease has been notably important to understand this heterogeneous spatial distribution. Many studies have tried to establish relationships between the disease and socioeconomic factors, based on different units of analysis such as census sectors and municipalities. However, few have examined the synthetic indicators of the existing socioeconomic performance regarding its ability in explaining the dynamics of the disease. ${ }^{7-9}$

It is assumed that this relationship is not just linear as cause-effect. There is a complex network of inter-relationships between socioeconomic factors and the occurrence of Hansen's disease. It is at this point that the spatial modeling of data and the combination of different mathematical models can help understand the phenomenon. Recently, these models have been in the spotlight of the health sector, for both diseases and injuries to human health. ${ }^{10-14}$

In view of what was discussed, the objective of this study was to analyze the spatial distribution of Hansen's disease in the State of Bahia and the association between its occurrence and the synthetic indicators of municipal socioeconomic performance, of social vulnerability and income inequalities.

\section{METHODS}

It is an ecological study in the territory of the State of Bahia, located in the northeastern region of Brazil, consisting of 417 municipalities. The period of the study comprehended an interval of 15 years (2001 to 2015).

Three indicators of monitoring of the elimination process of
Hansen's disease as a public health problem (dependent variables) were analyzed, as stated in the decree 149/2016, that "approves all guidelines for the vigilance, attention and elimination of Hansen's disease as a public health problem, with the aim of guiding health service managers and professionals". They are: i) annual coefficient of detection of new cases of Hansen's disease in the general population per 100.000 inhabitants; ii) annual coefficient of detection of new cases of Hansen's disease in younger than 15 years of age per 100.000 inhabitants; iii) coefficient of new cases of Hansen's disease with grade II of physical disability at the time of diagnosis per 100.000 inhabitants.

For the analysis, we adopted the classification as described in the above-mentioned legislation. Since the coefficient of grade II does not have established evaluation parameters, we adopted the same detection coefficient as in younger than 15 years of age..$^{15}$

To calculate the indicators, we collected data from new diagnosed cases according to the municipality of residence, extracted from the Sistema Nacional de Agravos de Notificação (SINAN). Cases closed as diagnostic error, recurrences and duplicate files were excluded. The populational data needed to calculate the indicators were obtained from the Instituto Brasileiro de Geografia e Estatística (IBGE), 2010 census and inter-census predictions.

The study was divided into two stages, the first being destined to spatial analysis of Hansen's disease in the State and the second destined to the association between the disease and the synthetic indicators of municipal performance.

In the first stage, the mean coefficients for the period (20012015) were calculated. The empiric local Bayesian model was used to soften the indicators with the aim of minimizing the random fluctuation of data from smaller areas and, therefore, providing more stability for the indicators. ${ }^{16-19}$ Of note, in 2010, according to census' data, only 16 (3.8\%) municipalities in Bahia had a population larger than 100.000 inhabitants. Besides this argument for the use of Bayesian model, there is also the problem of under-notification of the cases of the disease, resulting in a reduced number of events per municipality. The low number of cases leads to little representative and even distorted estimates of reality. In these cases, the Bayesian model is an important solution to obtain more accurate data. ${ }^{17,19}$

The objective of the model is to identify the distribution after the event (quantities not observed of a certain phenomenon) from the application of Bayes theorem, involving sampling data (likelihood function) and a group of observed data (distribution before the event). ${ }^{20-21}$ In the health sector, many authors have successfully used the softening method before applying the statistics of Moran. ${ }^{11,14,22-24}$

Subsequently, we tried to identify the existence of spatial dependency and autocorrelation of the epidemiological indicators using the global Moran's index (MI) and the pseudo significance test. The local autocorrelation (Local Index of Spatial Association - LISA) was evaluated through the local Moran's index. The scatter plot for Moran's I was generated from the local MI to identify critical or transition areas, through which we compare the value of each municipality to the neighboring municipalities. The generated quadrants were interpreted as: Q1-High/high (positive values and positive means); Q2-Low/low (negative values and negative means); Q3-High/low (positive values and negative means); and 
Q4-Low/high (negative values and positive means). Based on the results obtained from the scatter plot for Moran's I and the LISA, the theme maps LISA Map and Moran Map were created. LISA Map comes from the local Moran's index to identify different patterns of statistical significance. Moran Map is similar to LISA Map but only considers the areas whose Moran indexes were significant $(p<0.05)$. These areas are presented according to their location in the scatter plot of Moran's I (Q1, Q2, Q3 and Q4). ${ }^{21,25}$

In the second stage, the independent variables were defined: index of municipal human development (IMHD) and its dimensions (longevity, education and income) and the Gini and Theil-L indexes (income inequality) obtained from the 2010 census (IBGE); index of social vulnerability (ISV) and its dimensions (urban infrastructure, human capital and income and work), obtained from the Atlas of Social Vulnerability, Instituto de Pesquisas Econômicas Aplicadas (IPEA); FIRJAN index of municipal development (FIMD) and its dimensions (education, health and employment and income) obtained from the database of the Federação das Indústrias do estado do Rio de Janeiro (FIRJAN); and the socioeconomic performance index (IPESE) and its dimensions (education, health and economy and finances), obtained from the Superintendência de Estudos Econômicos e Sociais do Estado da Bahia (SEI-BA). All were based in the year of 2010.

Initially, we tried to identify the statistical correlation between the epidemiological indicators and the socioeconomic indicators using the bivariate analysis of Pearson (significance of 5\%). We opted to convert the indicators into logarithmic rates in order to guarantee data normality. Afterwards, the independent variables were submitted to the multivariate regression analysis (Ordinary Least Squares-OLS) with the aim of verifying the variables most associated to the outcome, as suggested by Anselin. ${ }^{26}$ To compose this model, independent variables with a significant correlation with the dependent variables were selected. We also verified the multicollinearity criterion among the variables from the observation of tolerance and the variance inflation factor.

The necessity of incorporation to spatial effects was evaluated next, analyzing the residue independence through Moran's index. Once the autocorrelation of residues was determined, the choice of the best model to be adopted took place with the application of Lagrange multiplier tests, as the decisive model proposed by Anselin et al. ${ }^{27}$ Two models are possible: Spatial Error Model and Spatial Lag Model. While the first considers spatial effects as inconveniences that should be removed, the second attributes to the variable response $\mathrm{Y}$ the ignored spatial autocorrelation. After the application of the model, we adopted the Akaike criteria (AIC) and Bayesian criteria of Schwarz (BIC), being the best model the one that shows the lowest values, and the likelihood log and coefficient of determination $\left(R^{2}\right)$, the best model being that with the higher values. We applied Moran's statistics to the residues of spatial models with the aim of quantitatively identifying if the spatial autocorrelation was eliminated.

ANOVA statistics was applied to compare epidemiological indicators among the layers of the socioeconomic indicators that composed the final regression model. We adopted the Tamhane T2 post hoc and significance of $5 \%$.

For the analyses, the software Terra View 4.2.2, provided by the Instituto Nacional de Pesquisas Espaciais (INPE); QGis 2.14.11, provided by Open Source Geospatial Foundation (OSGeo); GeoDa 1.8.10, provided by Center for Spatial Data Science - University of Chicago; and SPSS 22.0, provided by IBM Corporation were used. The territorial charts needed to create the maps were sourced from IBGE.

The study was approved by the committee of ethics in research of the Universidade Federal de Alagoas CAAE n. 70943617.5.0000.5013 and approval report n. 2.212.723/2017.

\section{RESULTS}

Between 2001 and 2015, based on SINAN's data, 42,227 new cases of Hansen's disease were notified in the State of Bahia, with a mean of $2,815.1$ cases/year. Of the total, $8.1 \%(n=3,430)$ of the patients were younger than 15 years, with a mean of 228.7 cases/ year. Grade II of physical disability at diagnosis was present in $4.8 \%$ $(n=2,032)$ of the individuals diagnosed.

The spatial distribution of the disease in the State is not homogeneous (Figure 1). Global Moran's index (I) showed that the three indicators had spatial autocorrelation: i) coefficient of general detection, $\mathrm{I}=506071$ ( $p=0.01)$; ii) coefficient of detection in younger than 15 years, $\mathrm{I}=0,41992(p=0.01)$; and iii) coefficient of physical disability grade II, $\mathrm{I}=0,726589(p=0.01)$.

The coefficient of general detection softened by the local empiric Bayesian model ranged from 0 to 270.8 cases/100.000 inhabitants. We observed that $3.6 \%(n=15)$ of the municipalities were classified as silent and 9,4\% ( $n=39)$ as hyperendemic (40 or more cases/100.000), with special attention to the municipalities of Andaraí, Barreiras, Belmonte, Guaratinga, Itabela and Remanso, with coefficients higher than 100 cases/100.000 (Figure 1).

The coefficient of detection of new cases in younger than 15 years of age ranged between 0 and 127/100.000. The rate of silent municipalities was of $52.5 \%(n=219)$. Of the municipalities, $8.9 \%$ $(n=37)$ were classified as hyperendemic (10 or more cases $/ 100.000$ inhabitants), with special attention to the municipality of Remanso, with the highest coefficient of the State (127.4/100.000), followed by the municipality of Belmonte (53.5/100.000) (Figure 1).

Of the 39 hyperendemic municipalities for the general population, $71.5 \%(\mathrm{n}=28)$ of them were also hyperendemic for the population younger than 15 years. Of the 37 hyperendemic municipalities for the population younger than 15 years, $21.6 \%$ $(n=08)$ were exclusively hyperendemic for this population. They are: Alcoçaba (11.7/100.000), Angical (13,3/100.000), Canavieiras (11,4/100.000), Caravelas (10,2/100.000), Ibiquera (11,7/100.000), Itagimirim (21,6/100.000), Jucuruçu (12,5/100.000) and Medeiros Neto (12,4/100.000) (Figure 1).

Regarding the coefficient of new cases with grade II physical disability, the indicator fluctuated between 0 and 4.7/100.000. the proportion of silent municipalities was of $69.1 \% \quad(n=288)$. The highest values were seen in Glória (4.7/100.000), Jucuruçu (3.68/100.000) and Guaratinga (3.42/100.000) (Figure 1).

LISA Map demonstrated that $69.3 \%(n=289)$ of the municipalities did not show statistical significance for the coefficient of general detection, with a similar phenomenon occurring for the coefficient in younger than 15 years, with $64.7 \%(n=270)$, and for the coefficient of cases with grade II, with $58.3 \%(n=243)$. Moran Map 


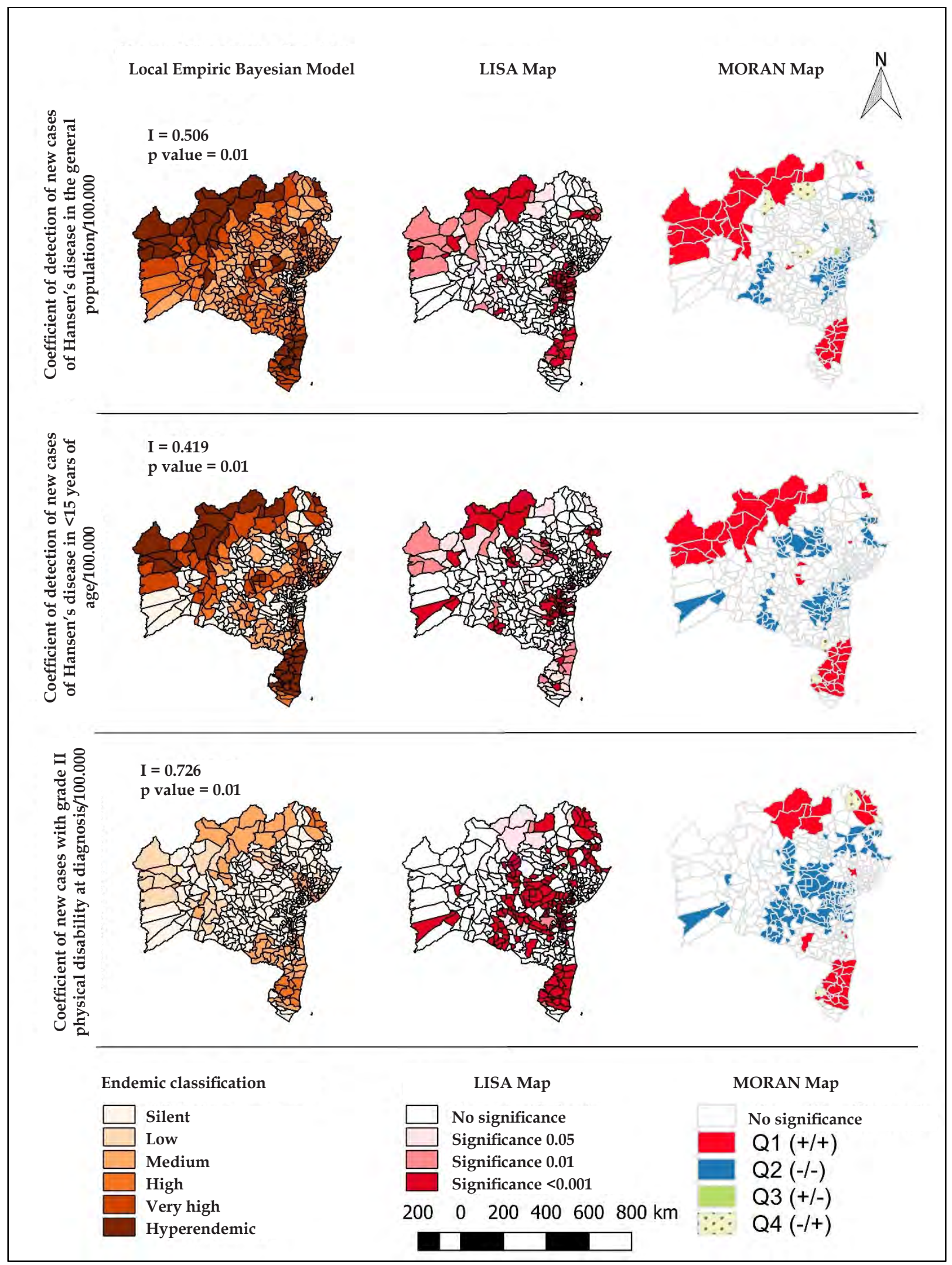

FIGURE 1. Spatial distribution of the coefficients of detection of new cases of Hansen's disease in the general population and in younger than 15 years of age and the coefficient of new cases with grade II physical disability softened by the empiric local Bayesian model. Bahia-Brazil, 2001-2015

Source: Author 
demonstrated that $10.1 \%(n=42)$ of the municipalities were classified as Q1 in the scatter plot of Moran, according to the coefficient of general detection; $10.8 \%(n=45)$, according to the coefficient in younger than 15 years; and $7.4 \%(n=31)$, according to the coefficient of grade II disability (Figure 1).

Observing figure 1 , it is possible to note that the most critical areas for the epidemiological indicators were the geographical axis from the northern region up to the west of the State, and the southern region for the coefficients of general detection and in younger than 15 years; and the northern, northeastern and southern regions for the coefficient of physical disability grade II. The municipalities of these regions were located in the quadrant Q1 (high-high) of Moran's scatter plot, since their mean and that of their neighbors is elevated. Few municipalities were located in the quadrants Q3 and Q4, considered as transition, with six for the coefficient of general detection, two for the coefficient in younger than 15 years of age and five for the coefficient of physical disability grade II.

In table 1, we can observe the correlation of Pearson among the epidemiological and socioeconomic indicators, with statistical significance. A positive correlation was found between IMHD and the coefficients of detection in the general population and in younger than 15 years. The dimension longevity of IMHD, FIMD and FIMD "health" was only correlated to the coefficient of general detection. The index of social vulnerability (dimension work and income) was inversely correlated to the coefficient of general detection. The indexes Theil-L and Gini were correlated to the coefficients of detection in younger than 15 years and with the coefficient of grade II physical disability. The three epidemiological indicators were correlated to the IPESE indicator and its dimension "economy and finances". Additionally, Moran's index demonstrated that all these indicators had a spatial dependency. It is worth highlighting that all correlations were considered weak.
IMHD mean was 0.594, classified as low IMHD (between 0.500 and 0.599 ). the municipalities with the highest IMHD were Salvador (0.759), Lauro de Freitas (0.754) and Barreiras (0.721). on the other hand, the municipalities of Itapirucu (0.486), Pilão Arcado (0.506) and Monte Santo (0.506) had the worst indexes. Regarding income inequality (Theil-L e Gini), the municipalities with the highest indexes were Maraú (0.98/0.71), Ipiaú (0.92/0.63) and Jaguarari $(0.88 / 0.59)$. the municipalities with lower inequality were Gavião (0.31/0.49), Caatiba (0.30/0.45) and Itambé (0.29/0.39).

Regarding FIMD, the municipalities Lauro de Freitas (0.747), Salvador (0.712) and Feira de Santana (0.699) had the highest values. The municipalities of Pilão Arcado (0.278), Gongogi (0.282) and Várzea do Poço (0.284) were the ones with the lowest values. The municipalities of Pojuca (0.741), São Francisco do Conde (0.748) and Madre de Deus (0.754) occupied the best ranking in IPESE. The municipalities of Pilão Arcado (0.337), Gentio do Ouro (0.378) and Buritirama (0.383) occupied the last positions.

After different models through multivariate regression, only the IPESE indicator "economy and finances" had a significant coefficient of regression for two dependent variables: coefficient of detection of new cases of Hansen's disease in the general population and in younger than 15 years. Although there was normality of residues, Moran's statistics showed that both had spatial dependency: coefficient of general detection (Moran's $\mathrm{I}=0.481, p=0.01$ ) and coefficient of detection in younger than 15 years (Moran's $\mathrm{I}=0.371$, $p=0.01)$.

The Spatial Error Model was the best indicated model by the multiplier tests of Lagrange in the robust version for the analysis of two epidemiological indicators (Robust LM-error, $p<0.001$ ). Table 2 compares the models OLS and Spatial Error for two dependent variables, having as the predicting variable IPESE "economy and finances". In the OLS model, normality of residues was observed

\begin{tabular}{|c|c|c|c|}
\hline Indicator & $\begin{array}{c}\text { Coefficient } \\
\text { of general } \\
\text { detection }\end{array}$ & $\begin{array}{l}\text { Coefficient } \\
\text { of detection } \\
\text { in }<15 \text { years }\end{array}$ & $\begin{array}{c}\text { Coefficient } \\
\text { of physical } \\
\text { disability }\end{array}$ \\
\hline IHMD & 0.143 & 0.113 & - \\
\hline IHMD Renda & 0.181 & 0.117 & - \\
\hline IHMD Longevity & 0.112 & - & - \\
\hline $\begin{array}{l}\text { ISV Work and } \\
\text { Income }\end{array}$ & -0.139 & - & - \\
\hline Theil-L & - & 0.145 & 0.100 \\
\hline Gini & - & 0.170 & 0.115 \\
\hline FIMD & 0.127 & - & - \\
\hline FIMD Health & 0.160 & - & - \\
\hline IPESE & 0.227 & 0.152 & 0.101 \\
\hline $\begin{array}{l}\text { IPESE Economy } \\
\text { and Finances }\end{array}$ & 0.236 & 0.190 & 0.133 \\
\hline
\end{tabular}

Source: Author

\begin{tabular}{|c|c|c|c|c|}
\hline \multirow[t]{2}{*}{ Criterion } & \multicolumn{2}{|c|}{$\begin{array}{c}\text { Coefficient of } \\
\text { general detection }\end{array}$} & \multicolumn{2}{|c|}{$\begin{array}{c}\text { Coefficient of } \\
\text { detection in the } \\
\text { population }<15 \text { years }\end{array}$} \\
\hline & OLS & $\begin{array}{l}\text { Spatial } \\
\text { Error } \\
\text { Model }\end{array}$ & OLS & $\begin{array}{l}\text { Spatial } \\
\text { Error } \\
\text { Model }\end{array}$ \\
\hline Intercept & $0.658306^{*}$ & $0.60942^{*}$ & 0.0321911 & 0.0456763 \\
\hline $\begin{array}{l}\text { IPESE } \\
\text { Economy and } \\
\text { Finances }\end{array}$ & $0.653489^{*}$ & $0.648926^{*}$ & $0.619965^{*}$ & $0.511448^{*}$ \\
\hline $\mathrm{R}^{2}$ & 0.052706 & 0.52536 & 0.065264 & 0.436949 \\
\hline Likelihood log & -267.072 & -142.095 & -197.772 & -109.621 \\
\hline Akaike (AIC) & 538.145 & 288.192 & 399.544 & 223.242 \\
\hline Schwarz (BIC) & 546.211 & 296.258 & 407.61 & 231.308 \\
\hline Moran's I & 0.481 & -0.049 & 0.371 & -0.022 \\
\hline
\end{tabular}

Source: Author * $\mathrm{p}$ value $<0.001$ 
both for the coefficient of general detection $(p=0.597)$ and the coefficient of detection in younger than 15 years $(p=0.436)$ and homoscedasticity ( $p=0.932$ and 0.115 , respectively).

We observed that the spatial regression model improved the results, since it brought upon a better explanatory power $\left(\mathrm{R}^{2}\right)$, amplification of the likelihood log and reduction of AIC and BIC. The final model was able to explain approximately $52 \%$ of the coefficient of detection of new cases of Hansen's disease in the general population and $43 \%$ in the population younger than 15 years.

Figure 2 shows the spatial distribution of the residues of the models of classic regression and Spatial Error, as well as the Moran Map of these residues. The application of the model of spatial regression practically eliminated the spatial dependency of the coefficient of detection of new cases of Hansen's disease in the general population $(\mathrm{I}=-0.049, p=0.009)$ and completely eliminated the dependency of the coefficient of detection of new cases in the population younger than 15 years ( $\mathrm{I}=-0.022, p=0.16$ ).

Finally, the municipalities were compared according to IPESE's classification "economy and finances" (Table 3). Of the $417 \mathrm{mu}-$ nicipalities studied, 37 of them were classified as high or very high performance ( 0.700 to 1.00$) ; 50$, as medium performance $(0.500$ to 0.699 ); 243 , as low (0.300 to 0.499 ); and 87 , as very low (0 to 0.299 ). we observed that the municipalities situated in the very high/high and medium rank had a higher burden of Hansen's disease, with statistically significant differences when compared to the municipalities with low or very low performance.

\section{DISCUSSION}

The heterogeneity in the spatial distribution of Hansen's disease in the State of Bahia resembles that of the regional and national patterns. The spatial pattern has been shown both in studies involving large areas, such as municipalities and States, and in small areas, as with the census sectors. Imbiriba $e a^{28}$, in a study conducted in Manaus (AM), demonstrated, for example, that the neighboring census sectors had disparate characteristics, whereas in some distant areas had similar coefficients. In our study, the most critical areas were notably concentrated in the north-west axis and in the southern region of the State.

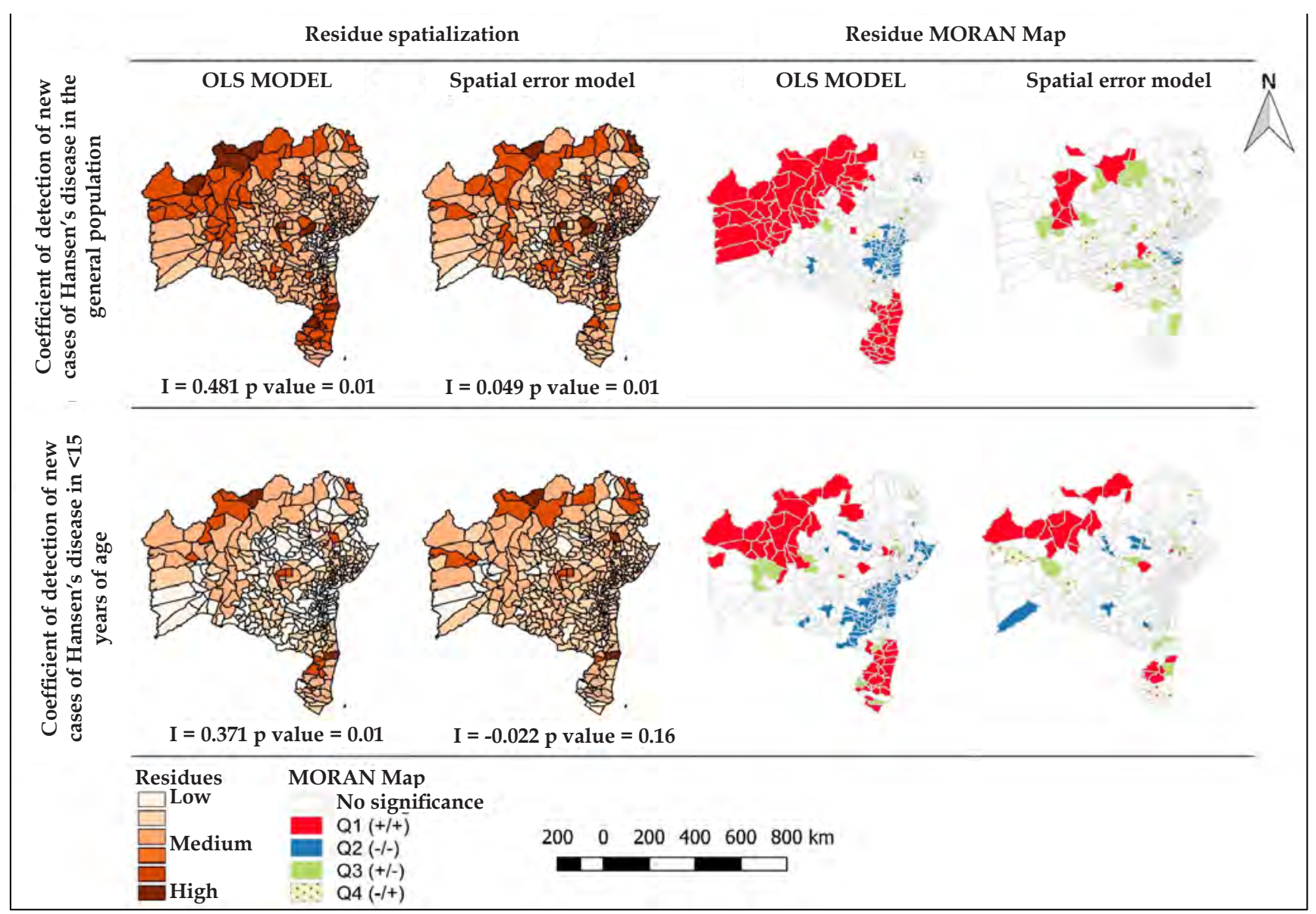

Figure 2: Spatialization and Moran Map of the residues of the models of classic regression (OLS) and Spatial Error of the coefficients of detection of new cases of Hansen's disease in the general population and in younger than 15 years of age. Bahia-Brazil, 2001-2015 Source: Author 
TABLE 3: Analysis of the epidemiological indicators of Hansen's disease according to the level of the socioeconomic performance index - economy and finances. Bahia-Brazil, 2001-2015

Index of socioeconomic performance - economy and finances, 2010

\begin{tabular}{lcccccc}
\hline Variable & $\begin{array}{c}\text { Very high and } \\
\text { high }(1)(\mathrm{n}=37) \\
24.8 \pm 22.3\end{array}$ & $\begin{array}{c}\text { Medium }(2) \\
(\mathrm{n}=50)\end{array}$ & $\begin{array}{c}\text { Low }(3) \\
(\mathrm{n}=243)\end{array}$ & $\begin{array}{c}\text { Very low }(4) \\
(\mathrm{n}=87)\end{array}$ & Anova & Groups \\
$\begin{array}{l}\text { Coefficient of general } \\
\text { detection }\end{array}$ & $5.27 \pm 5.7$ & $5.72 \pm 9.1$ & $2.46 \pm 8.8$ & $2.32 \pm 4.7$ & $\mathrm{p}=0.015$ & 1 vs 4 \\
$\begin{array}{l}\text { Coefficient of detection } \\
\text { in }<15 \text { years }\end{array}$ & $0.64 \pm 0.7$ & $0.68 \pm 1.0$ & $0.24 \pm 0.6$ & $0.18 \pm 0.46$ & $\mathrm{p}<0.001$ & 1 vs $(3,4) 2$ vs $(3,4)$ \\
$\begin{array}{l}\text { Coefficient } \text { of grade II } \\
\text { physical disability }\end{array}$ & & & $12.9 \pm 22.9$ & $12.1 \pm 13.0$ & $\mathrm{p}<0.001$ & 1 vs $(3,4) 2$ vs $(3,4)$ \\
\hline
\end{tabular}

Source: Author

In these regions, a peculiar migratory pattern was observed. The south of the State, known by cocoa and cellulose production, attracted many immigrants throughout the decades in search of better quality of life. Nonetheless, in the last few years of the $20^{\text {th }}$ century, with a crisis in the coca sector due to an intense loss of crops affected by the fungus Crinipellis perniciosa, there was an intense outflow of farmers towards the cities, mainly Itabuna and Ilhéus. In them, these workers occupied the peripheries and lived in precarious conditions, particularly regarding housing, education, health, nutrition and sanitation. ${ }^{29}$

In the northern region of the State, where the Vale do São Francisco is located, the installation of projects of regional development aimed at irrigated fruit farming resulted in an intense migratory flow, even considering the low salaries offered to workers. ${ }^{30}$ In 2010 , for example, $35.4 \%$ of the individuals living in the municipality of Juazeiro were immigrants, corresponding to over 70.000 people that year. It is obvious that this process brought about positive aspects for the region but, on the other hand, the population growth did not correspond to the needed urban improvement, what put workers in conditions of social vulnerability due to the little or no access to minimal living conditions, such as sanitation, education and health. ${ }^{30}$

A similar process occurred in the west of Bahia. The development of agriculture, mainly because of soy plantations, the low prices of the lands and the Government incentives created opportunity for a large number of people to move from different regions of the country looking for new opportunities. As in Vale do São Francisco, in the west of the State, particularly in the municipality of Barreiras, the growth was not accompanied by urban development, prevailing socio-spatial inequalities. ${ }^{31}$

These areas of uncontrolled growth and the formation of clusters in a context of poverty, particularly at the cities surroundings, make individuals more susceptible to contamination with Mycobacterium leprae and allow for the maintenance of areas in which the epidemiological chain of transmission is kept active. These populations live in unfavorable social, economic, sanitary, housing and dietary conditions, enhancing the occurrence of the disease, contamination of children and the appearance of physical disabilities. For many authors, the migratory process that generates unfavorable socioeconomic contexts can be associated to the occurrence of Hansen's disease. ${ }^{9,28,32,33}$

Although Hansen's disease is associated to poor living conditions of the population, when analyzing IHMD, we found a relationship of the disease with a higher per capita income and longevity. This finding shows that the relationship between Hansen's disease and development is not purely linear or cause-effect, where the low development is associated to higher disease burden. This assertion is based in the fact that we found a positive correlation between the indicators of human development and socioeconomic performance and the epidemiological indicators, i.e., the municipalities with the best indicators were those with the highest detection of the disease, which can have many different explanations as seen below.

IHMD is a synthetic indicator composed of three dimensions: longevity (life expectancy at birth), education (level of education of the adult population and school flow of the younger population) and income (per capita income). The dimensions "income and longevity" had a relationship with Hansen's disease. Because it is a disease with a long incubation period, it is expected that in endemic areas the increased life expectancy increases the likelihood of the occurrence of new cases. The dimension "income" is related to access to services such as health and education, and the better access can explain the higher number of diagnoses.

Far beyond considering municipal development, it is necessary to think how it took place, since it represents a global synthesis. In the study, we observed that municipalities with the highest HDI also had the highest indexes of income inequality, being this an important topic for analysis. The relationship between inequalities (indexes of Gini and Theil-L) and Hansen's disease was demonstrated in different studies. Freitas et al ${ }^{9}$ showed that the Brazilian municipalities with higher inequality are those with higher disease burden.

The synthetic indicator that showed a better relationship with the epidemiological indicators was IPESE and its dimension "economy and finances", being the only variable able to compose the final explanatory model. The final model was possibly composed solely by this indicator due to the weak correlation observed in the other variables analyzed. Another factor to be mentioned is the influence of the number of units of analysis (417 municipalities).

IPESE originates from the combination of two other indexes, the index of social development and the index of economic development, and its objective is to measure the ability of the mu- 
nicipalities in meeting the needs of the population regarding basic services and the quality of these services. The dimension "economy and finances" takes four indicators into consideration, two of them related to the dynamics of the labor market (indexes of income of the formal worker and formal employment) and two related to the economic and financial dynamics of the municipalities (indexes of municipal product and financial independence).

The fact that the municipalities classified as very high and high performance have higher epidemiological indicators when compared to those classified as low or very low performance in IPESE's "economy and finances" could be explained by the relationship between income and access to health services (index of income of the formal worker, that reflects the mean rentability of formal workers compared to Brazil's level; and the index of formal employment, that measures the proportion of formal employment in the municipality). The increased income of individuals considerably enhances the chance of seeking a health service. ${ }^{34-36}$ Formal employment is indicated by $e t a l^{37}$ as a determinant of the access, since according to these authors, being employed and having a contract increases the likelihood of seeking attention in these services. ISV reinforces this hypothesis since we observed an inverse relationship of this indicator with disease detection, evidencing that social vulnerability, materialized by the poor living conditions, hinders diagnosis.

The two following explanations are more specifically related to the indexes of municipal product and financial independence. While the first captures the level of gross domestic product (GDP) per capita of the municipality in comparison with the national level, the second index captures the ability of the municipality in financing its activities and offering services to the population.

The first explanation refers to the economic-financial increment in the general infrastructure of the municipalities and its impact in seeking and accessing health services by part of the population. Neri and Soares ${ }^{35}$ showed that individuals with more access to water, sanitation, garbage collection and electricity public services have higher chances of seeking health units when compared to those that do not have access to these services.

The following explanation is related to the impact of the indicators in their own local health system. As the municipalities increase their revenues, the financial amount to be compulsory invested in the health sector also increases, obeying the minimum percentage of $15 \%$, as established in the article n. 198 of the Federal Constitution of 1988, regulated by the Complementary Law n. 141/2012. Besides the Constitution itself, the Law of Fiscal Responsibility (Complementary Law n. 101/2000) prevents the voluntary transfer of the country's and the State's resources to the municipalities in case of non-compliance of the application of the established minimum percentage.

After establishing health as a social right and the Sistema Único de Saúde as a way of ensuring this right, management and planning tools were developed to enhance the country's, States' and municipalities' ability of investing in health actions and services. Among these tools, the Plano Plurianual (PPA), the Plano de Gestão, the Agenda de Saúde, the Plano Diretor de Regionalização (PDR), the Programação Pactuada e Integrada, the Lei de Diretrizes Orçamentárias (LDO) and the Lei Orçamentária Anual (LOA) are highlighted. These tools have an essential function to ensure the application of public resources in the strengthening of the health system. ${ }^{38}$

Initially, this scenario is capable of explaining an increase of new diagnosed cases in the municipalities for a reduction to be seen only later in the coefficients, what does not mean that people get sicker in the municipalities with better performance but only that there are more diagnoses and the under-notification in these areas is lower than in municipalities with worse economic and financial conditions. The same rationale can be applied to FIMD, the reason why a positive correlation between this indicator and the detection of Hansen's disease in the general population was found.

The non-relationship between the dimension "health" and the epidemiological indicators can be explained by the fact that this dimension contemplates seven indexes, among which are those that are not associated to the epidemiology of Hansen's disease, such as indexes of pre-natal consultations, the index of deaths with a defined cause, the index of vaccination coverage and the index of hospitalization for unavoidable causes. The same rationale can be applied to the dimension "education", composed by five elements, among which none is related to the disease: index of enrollment in pre-school, index of enrollment in high school, index of quality of primary school (first years), index of enrollment in primary school and index of quality of primary school (final years). ${ }^{39}$

One limitation of this study refers to the fact that it only analysis synthetic indicators, disregarding the existing socio-spatial differences within the municipality, what could initially mask the true relationship between development and Hansen's disease. The thorough look on this finding makes it possible to suggest that these areas have more cases diagnosed due to a higher supply and better access to services, not only health but also education, housing and sanitation, considered to be social determinants of the process of getting sick, what does not lead to the understanding that Hansen's disease is linked to wealth standards, since its relationship with income inequality was demonstrated.

A second limitation refers to the fact that these indicators are made by the combination of diverse variables, aggregated into one index, what could make the identification and contribution of each isolated component difficult in the social determination of the disease. For example, the dimension health was nor correlated to the occurrence of Hansen's disease but, if we analyze the ungrouped variables, we would possibly find a relationship with the Estratégia Saúde da Família (ESF) coverage, as pointed by Freitas et al. ${ }^{9}$ Therefore, we evidence the need of creating a specific explanatory model from ungrouped variables.

\section{CONCLUSIONS}

The spatial analysis showed that Hansen's disease has a heterogeneous distribution in the State of Bahia, concentrated in the north-west axis and in the south of the State.

The synthetic indicators analyzed revealed the complex relationship between municipal development and the process of being affected by Hansen's disease, with a thorough analysis being needed on this topic because at the same time that we demonstrated a positive relationship between the disease and the indicators of human development, we also observed an equal relationship of 
Hansen's disease with income inequality, evidencing the polysemy of this phenomenon.

More than analyzing a synthetic indicator, it is necessary to understand how the same indicator is distributed intra-locally. The most concrete explanation is that, the higher the development of the municipality, the more access the population will have to health services, having as an immediate consequence the increase in the coefficients of detection of new cases. On the other hand, the poor conditions that favor the disease itself make the diagnosis difficult.

IPESE's "economy and finances" was the indicator with the best correlation to the disease, integrating the final model. The re- lationship could be explained by the improvement in the workers income and their connections to health services access, besides the effects of this outcome in the cross-sectional factors that enhance the individuals' access (education, sanitation, access to water) and the direct effects in the investments in the health sector.

In view of the limitations of this study, we recommend that other studies are conducted using ungrouped variables, making possible the creation of an explanatory model that shows the connections of Hansen's disease and its determinants.

\section{REFERENCES}

1. Lockwood DN, Lucas SB, Desikan KV, Ebenezer G, Suneetha S, Nicholls P. The histological diagnosis of leprosy type 1 reactions: identification of key variables and an analysis of the process of histological diagnosis. J Clin Pathol. 2008;61:595-600

2. Pires CAA, Miranda MFR, Bittencourt MJS, Brito AC, Xavier MB. Comparison between histopathologic features of leprosy in reaction lesions in HIV coinfected and non-coinfected patients. An Bras Dermatol. 2015;90:27-34.

3. Bahia El Idrissi N, Das PK, Fluiter K, Rosa PS, Vreijling J, Troost D, et al. M. leprae components induce nerve damage by complemente activation: identification of lipoarabinomannanas the dominant complement activator. Acta Neuropathol. 2015;129:653-67.

4. White C, Franco-Paredes C. Leprosy in the 21st century. Clin Microbiol Rev. 2015;28:80-94

5. Apps.who.int [Internet]. World Health Organization. Global leprosy strategy: Accelerating towards a leprosy-free world. [cited 2017 Aug 03]. Available from: http://apps.who.int/iris/bitstream/handle/10665/208824/9789290225096 en.pdf? sequence $=14$ \&isAllowed $=y$.

6. Portalarquivos.saude.gov.br [Internet]. Brasil. Ministério da Saúde. Sistema de Informação de Agravos Notificáveis/SINAN. Registro ativo: número e percentual. Casos novos de hanseníase: número, coeficiente e percentual, faixa etária, classificação operacional, sexo, grau de incapacidade, contatos examinados, por estados e regiões [acesso 25 mar 2017]. Disponível em: http://portalarquivos. saude.gov.br/images/pdf/2016/julho/07/tabela-geral-2015.pdf.

7. Souza LR. Condicionantes sociais na delimitação de espaços endêmicos da hanseníase [tese]. São Paulo (SP): Universidade de São Paulo; 2012. 301p.

8. Cury MRCO, Paschoal VD, Nardi SMT, Chierotti AP, Rodrigues Júnior AL, Chiaravalloti-Neto F. Spatial analysis of leprosy incidence and associated socioeconomic factors. Rev. Saúde Pública. 2012;46:110-8.

9. Freitas LRS, Duarte EC, Garcia LP. Leprosy in Brazil and its association with characteristics of municipalities: ecological study, 2009-2011. Trop Med Int Health. 2014;19:1216-25.

10. Santos VR, Yokoo EM, Souza-Santos R, Atanaka-Santos M. [Socioenvironmental factors associated with the spatial distribution of malaria in the Vale do Amanhecer settlement, Municipality of Juruena, State of Mato Grosso, 2005]. Rev Soc Bras Med Trop. 2009.42:47-53.
11. Silva PHNV, Lima MLC, Moreira RS, Souza WV, Cabral APS. Spatial study of mortality in motorcycle accidents in the State of Pernambuco, Northeastern Brazil. Rev Saúde Pública. 2011:45:409-15.

12. Carvalho AX, Silva GD, Almeida Júnior GR, Albuquerque PH. Bayesian rates for homicide mapping in Brazilian municipalities. Cad Saúde Pública. 2012;28:1249-62.

13. Duarte-Cunha M, Cunha GM, Souza-Santos R. Geographical heterogeneity in the analysis of factors associated with leprosy in an endemic area of Brazil: are we eliminating the disease? BMC Infect Dis. 2015; 15:196.

14. Monteiro LD, Martins-Melo RF, Britol AL, Alencar CH, Heukelbachl J. Spatial patterns of leprosy in a hyperendemic state in Northern Brazil, 2001-2012. Rev Saúde Pública. 2015;49:84.

15. Portal.saude.pe.gov.br [Internet]. Brasil. Ministério da Saúde. Secretaria de Vigilância em Saúde. Departamento de Vigilância das Doenças Transmissíveis. Diretrizes para vigilância, atenção e eliminação da Hanseníase como problema de saúde pública: manual técnico-operacional [acesso 03 ago 2017] Disponível em: http://portal.saude.pe.gov.br/sites/portal.saude.pe.gov.br/files/diretrizes para . eliminacao_hanseniase_-_manual_-_3fev16_isbn_nucom_final_2.pdf.

16. Assunção $\overline{R M}$, Barreto $\bar{S} \bar{M}$, Guerra $\bar{H}$ L, Sakurai E. Maps of epidemiological rates: a Bayesian approach. Cad. Saúde Pública. 1998;14:713-23.

17. Catelan D, Lagazio C, Biggeri A. A Hierarchical Bayesian approach to multiple testing in disease mapping. Biom J. 2010;52:784-97.

18. Carvalho AX, Silva GD, Almeida Júnior GR, Albuquerque PH. Taxas bayesianas para 0 mapeamento de homicídios nos municípios brasileiros. Cad. Saúde Pública. 2012;28:1249-62.

19. Nunes FG. Abordagem bayesiana na epidemiologia espacial de notificacões de casos de dengue no Estado de Goias. In: Anais do XVI Simpósio Brasileiro de Sensoriamento Remoto (SBSR); 2013 Abr 13-18; Foz do Iguaçu, Paraná. São José dos Campos: INPE; 2013. p. 8554-8560.

20. Gelman A, Carlin JB, Stern HS, Rubin DB. Bayesian data analysis. London: Chapman \& Hall; 1995

21. Ministério da Saúde, Fundação Oswaldo Cruz; Santos SM, Souza WV, organizadores. Introdução à Estatística Espacial para a Saúde Pública. Rio de Janeiro: Fiocruz; Brasilila, DF: Ministério da Saúde; 2007. (Série B. Textos Básicos de Saúde - Capacitação e Atualização em Geoprocessamento em Saúde, v. 3). 
22. Martins-Melo FR, Lima MS, Alencar CH, Ramos Jr AN, Carvalho FHC, Machado MMT, et al. Temporal trends and spatial distribution of unsafe abortion in Brazil, 1996-2012. Rev. Saúde Pública. 2014;48:508-20.

23. Magalhães MAFM. A tuberculose no espaço urbano: Um estudo ecológico utilizando análise espacial no município do Rio de Janeiro nos anos de 2005 a 2008 [tese]. Rio de Janeiro (RJ): Universidade Federal do Rio de Janeiro; 2014. 111p.

24. Pereira AGL, Medronho RA, Escosteguy CC, Valencia LIO, Magalhães MAFM. Spatial distribution and socioeconomic context of tuberculosis in Rio de Janeiro, Brazil. Rev. Saúde Pública. 2015;49: 48.

25. Druck S, Carvalho MS, Câmara G, Monteiro AVM, editores. Análise espacial de dados geográficos. Brasília: EMBRAPA; 2004.

26. Anselin L. Exploring spatial data with GeoDa: a workbook. Urbana (IL): University of Illinois; 2005.

27. Anselin L, Florax RJ. Small sample properties of tests for spatial dependence in regression models: Some further results. In: Anselin L, Florax RJ, editors. New Directions in Spatial Econometrics. Berlin: Springer-Verlag.1995. p. 21-74.

28. Imbiriba ENB, Silva Neto AL, Souza WV, Pedrosa V, Cunha MG, Garnelo L. Social inequality, urban growth and leprosy in Manaus: a spatial approach. Rev Saúde Pública. 2009;43:656-65.

29. Andrade MLN. Um estudo cultural do cacau com perspectivas para 0 turismo [dissertação]. Ilhéus (BA): Universidade Estadual de Santa Cruz; 2004. 243p.

30. Vilarim MA. A região de Petrolina - PE e Juazeiro - BA: notas sobre as transformações locais, os sujeitos do campo e a migração. In: Anais do XI Encontro Nacional da Anpege; 2015 Out 09-12; Presidente Prudente, São Paulo. São Paulo: UFGD Editora; 2015. p.11249-260.
31. Costa DH, Mondardo ML. A modernização da agricultura no Oeste Baiano: Migração Sulista e novas territorialidades. Rev. Geonorte. 2013;7:1347-61.

32. Kerr-Pontes LR, Montenegro AC, Barreto ML, Werneck GL, Feldmeier H. Inequality and leprosy in Northeast Brazil: an ecological study. Int J Epidemiol. 2004;33:26269.

33. Murto C, Ariza L, Alencar CH, Chichava OA, Oliveira AR, Kaplan C, et al. Migration among individuals with leprosy: a population-based study in central Brazil. Cad Saúde Pública. 2014;30:487-501.

34. Noronha KV, Viegas M. Desigualdades sociais em saúde: Evidências empíricas sobre 0 caso brasileiro. Rev Econ NE. 2002;32:877-97.

35. Neri M, Soares W. [Social inequality and health in Brazil]. Cad. Saúde Pública. 2002;18 Suppl:77-87.

36. Andrade MV, Noronha KVMS, Menezes RM et al. Desigualdade socioeconômica no acesso aos serviços de saúde no Brasil: um estudo comparativo entre as regiōes brasileiras em 1998 e 2008. Econ. Apl. 2013;17:623-645.

37. Travassos C, Viacava F, Fernandes C, Almeida CM. Desigualdades geográficas e sociais na utilização de serviços de saúde no Brasil. Ciênc. Saúde Colet. 2000;5:133-149.

38. Brasil. Ministério da Saúde. Conselho Nacional de Secretários de Saúde (CONASS). Para entender a gestão do SUS / Conselho Nacional de Secretários de Saúde. Brasilia: CONASS; 2003.

39. Freitas URP, Queiroz AG, Espirito Santo JS, Silva JS. IPESE: Uma análise da performance socioeconômica dos municípios baianos. Revista de Desenvolvimento Econômico. 2016:1:38-69.

\section{AUTHORS'CONTRIBUTIONS}

Carlos Dornels Freire de Souza

iD ORCID 0000-0003-0837-8254

Statistical analysis; Approval of the final version of the manuscript; Conception and planning of the study; Elaboration and writing of the manuscript; Obtaining, analyzing and interpreting the data; Effective participation in research orientation; Critical review of the literature; Critical review of the manuscript

Carlos Feitosa Luna

iD ORCID 0000-0001-9277-4086

Statistical analysis; Approval of the final version of the manuscript; Conception and planning of the study; Elaboration and writing of the manuscript; Obtaining, analyzing and interpreting the data; Effective participation in research orientation; Critical review of the literature; Critical review of the manuscript

Mônica de Avelar Figueiredo Mafra Magalhães (iD) ORCID 0000-0002-6595-8274

Statistical analysis; Approval of the final version of the manuscript; Elaboration and writing of the manuscript; Effective participation in research orientation; Critical review of the literature; Critical review of the manuscript

How to cite this article: Souza CDF, Luna CF, Magalhães MAFM. Spatial modeling of leprosy in the state of Bahia and its social determinants: a study of health inequities. An Bras Dermatol. 2019;94(2):182-91. 